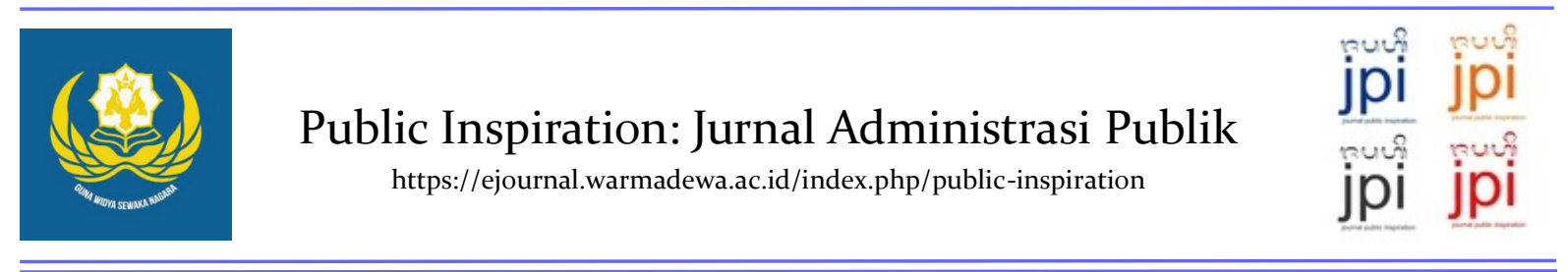

\title{
Tantangan Ilmu Administrasi Publik: Paradigma Baru Kepemimpinan Aparatur Negara
}

\author{
Johanes Basuki \\ STIA LAN Jakarta, Indonesia \\ Corespondence E-mail:j_basukio7@yahoo.com
}

How to Cite: Basuki, J. (2021). Tantangan Ilmu Administrasi Publik: Paradigma Baru Kepemimpinan Aparatur Negara. Public Inspiration: Jurnal Administrasi Publik, 6(2): 160-181. DOI: https:// doi.org/10.22225/pi.6.2.2021.160-181

\begin{abstract}
The greatest challenge of leaders in 21st century is how to be effective leaders. The era of which leaders are expected to make a change with new paradigm in public administration and management, have capability in managing information, productive, and science and technology basis. The new paradigm of leadership of government apparatus is transformational, transactional, resonant, serve public, and have vision. The most important is leader with self-esteem who respects to values for achieving successful and prosperity.
\end{abstract}

Keywords: Public Administration; New Paradigm; Leadership; Public Pparatus.

\section{Abstrak}

Tantangan terbesar para pemimpin di abad 21 adalah bagaimana menjadi pemimpin yang efektif. Era dimana pemimpin diharapkan melakukan perubahan dengan paradigma baru dalam administrasi dan manajemen publik, memiliki kemampuan dalam mengelola informasi, produktif, dan berbasis ilmu pengetahuan dan teknologi. Paradigma baru kepemimpinan aparatur pemerintah adalah transformasional, transaksional, bergema, melayani publik, dan berwawasan. Yang terpenting adalah pemimpin dengan harga diri yang menjunjung tinggi nilai-nilai untuk mencapai kesuksesan dan kemakmuran.

Kata kunci: Administrasi Publik; Paradigma Baru; Kepemimpinan; Aparatur Publik.

\section{Pendahuluan}

Kepemimpinan bukan sesuatu yang baru namun tetap relevan dan penting dikaji oleh para teoritisi, praktisi, politisi dan bahkan oleh masyarakat pada umumnya. Banyaknya perhatian terhadap kepemimpinan, mengingat peran stratejik dalam tatanan organisasi baik negara/ pemerintah, dunia usaha maupun organisasi masyarakat. Dalam konteks sistem administrasi negara, peran kepemimpinan aparatur negara menjadi sangat penting, karena diyakini sebagai faktor penentu arah perjalan suatu bangsa. Selain stratejik dan perannya tersebut, beberapa pertimbangan lainnya adalah:

Pertama, pada dasarnya, proses transformasi dalam berbagai bidang kehidupan yang multidimensional berlangsung dalam sistem dan melalui proses administrasi publik. Oleh sebab itu, adalah beralasan dan merupakan tanggungjawab intelektual dan moral segenap teoritisi dan praktisi administrasi pada organisasi manapun untuk memberikan jawaban atas berbagai permasalahan dan tantangan pembangunan yang dihadapi bangsa dan negara kita.

Kedua, bahwa reformasi administrasi publik yang selama ini dilakukan hanya diarahkan pada masalah sumber daya manusia aparatur, kelembagaan dan sistem serta tatalaksana ternyata belum mampu memberikan sumbangan yang signifikan. Model pelayanan yang hanya menekankan pada sistem dan aspek teknis pelayanan dengan sasaran pada para petugas pelayanan, juga belum memberikan hasil yang memuaskan. Apabila 
ditelusuri penyebabnya, salah satunya karena kurangnya perhatian terhadap reformasi terhadap aspek kepemimpinan aparatur negara. Disebut demikian, menurut kaidah para pemimpin adalah manusia- manusia super yang memiliki kelebihan dari yang lain, kuat, gigih, bersemangat dan tahu segalanya. Para pemimpin juga merupakan manusia-manusia yang jumlahnya sedikit, namun perannya dalam organisasi merupakan penentu keberhasilan dan suksesnya tujuan organisasi yang hendak dicapai.

Dalam sejarah peradaban manusia, gerak hidup dan dinamika organisasi sedikit banyak tergantung pada sekelompok kecil manusia penyelenggara organisasi. Bahkan dapat dikatakan kemajuan umat manusia datangnya dari sejumlah kecil orang-orang istimewa yang tampil kedepan membawa kelompok atau bangsanya kearah suatu tujuan yang hendak dicapai. Orang-orang ini adalah perintis, pelopor, ahli-ahli pikir, pencipta dan ahli organisasi. Sekelompok orang-orang istimewa inilah yang disebut "pemimpin"

Ketiga, dilihat dari perspektif administrasi publik, bahwa tantangan. Abad ke-21 menuntut paradigma baru manajemen, pemimpin perubahan dan kemampuan mengelola informasi serta produktivitas pegawai berbasis ilmu pengetahuan. Tuntutan ini sebagai konsekuensi logis tuntutan masyarakat terhadap pemerintah yang cenderung makin tinggi baik kuantitas maupun kualitasnya. Kecenderungan ini harus diikuti suatu pelayanan aparatur negara yang makin berkualitas. Paradigma lama yang menempatkan masyarakat yang melayani aparatur negara harus dilakukan perubahan secara mendasar dan tuntas. Para pemimpin di lingkungan aparatur negara yang hakikatnya merupakan aktor utama dan panutan harus melakukan perubahan-perubahan khususnya dalam mindset-nya.

\section{Hasil dan Pembahasan}

\section{Tantangan Administrasi Publik}

Apabila diidentifikasi secara cermat, berdasarkan perkembangan keadaan, cukup banyak tantangan yang dihadapi administrasi publik, saya mencatat paling tidak terdapat 21 tantangan yang dihadapi administrasi publik, yakni, (1) globalisasi ekonomi, (2) pendidikan, (3) pengangguran, (4) tanggung jawab sosial, (5) pelestarian lingkungan hidup, (6) peningkatan kualitas hidup, (7) penerapan norma- norma moral clan etika, (8) keanekaragaman tenaga kerja, (9) pergeseran konfigurasi demografi, (10) penguasaan dan pemanfaatan IPTEK, (11) tantangan di bidang politik, (12) bencana alam (tsunami, gempa, banjir (disaster management), (13) pemanasan global, (14) kesenjangan sosial, (15) manajemen multikultural, (16) paperless bureaucracy, (17) global competition, (18) customer loyalty problem, (19) knowledge base economy; (20) time to market, dan (21) kualitas kepemim- pinan. Adapun menurut Ginandjar Kartasamita (Orasi Ilmiah: 2007), tantangan besar yang dihadapi administrasi publik dihampir semua negara, adalah, prevalensi dart patologi birokrasi, yaitu kecenderungan mengutamakan kepentingan sendiri (selfseruing), mempertahankan statusnya dan resisten terhadap perubahan, cenderung terpusat (centralized), dan dengan kewenangannya yang besar, sering kali memanfaatkan kewenangan itu untuk kepentingan sendiri.

Dari patologi birokrasi tersebut, dapat ditambahkan 9 (sembilan) patologi birokrasi, yakni; (1) kekurangmampuan pimpinan menerapkan gaya kepemimpinan yang tepat; (2) orientasi kekuasaan dan bukan pada pelayanan (3) rendahnya profesionalisme birokrasi pemerintah; (4) primordialisme, kronisme, dan nepotisme; (5) sikap mengabaikan normanorrna moral clan etika; (6) tidak taat azas (7) perilaku disfungsional para birokrasi, clan (8) budaya organisasi yang tidak kondusif dalam penciptaan, penumbuhan, dan pemeliharaan etos kerja yang tercermin dalam loyalitas kepada negara, disiplin kerja, kepatuhan, dan ketekunan, serta (9) inkonsistensi kebijakan yang berdampak pada makin menurunnya tingkat kepercayaan masyarakat dan dunia usaha terhadap pemerintah.

Sebagai ilmu yang · bersifat interdisiplin, tantangan administrasi publik menunjukkan menyentuh hampir semua aspek kehidupan organisasional yakni ekonomi, sosial, budaya, 
politik dan etika serta moral. Mengingat luas wilayah perrnasalahan yang dihadapi, pada kesempatan ini hanya beberapa yang diungkap utamanya yang yang relevan dengan fokus bahasan.

Terkait dengan hal tersebut, berdasarkan hasil kajian B. Guy Peters (2003: 2), menemukan bahwa reformasi dan peningkatan kinerja organisasi memiliki korelasi yang signifikan dengan kepemimpinan dan kompetensi para pemimpin organisasi pemerintah dan dunia usaha. Anderson (http.//www. quesia.publicadmin.com, 2007), mengingatkan bahwa tantangan administrasi publik sebagai dampak globalisasi adalah terjadinya benturan budaya dan menurunnya nilai- nilai lokal yang mengakibatkan para pimpinan administrasi publik dituntut harus mampu secara terns menerus menyesuaikan diri terhadap perubahan yang terjadi. Berdasarkan hasil analisisnya, konsekuensi dari perubahan-perubahan yang tetjadi, harus diikuti pergeseran paradigma dalam penyelenggaraan pemerintahan negara, termasuk di dalamnya perubahan "mindset" nya.

John Gray, dalam bukunya Limited Government: A Positive Agenda (1989: 11-15), menyimpulkan bahwa dalam arena perubahan yang dinamis, perdebatan mengenai peranan administrasi publik dalam sistem ekonomi tampaknya memang cenderung mengarah kepada upaya untuk memberikan agenda positif bagi pemerintah untuk memainkan peranan yang kondusif. Gray menawarkan, meskipun dewasa ini beban kerja dan aktivitas pemerintah telah begitu besar, yang dibutuhkan bukanlah pemerintahan minimum, akan tetapi suatu kerangka peme- rintahan yang terbatas dengan agenda tanggungjawab yang positif atau yang disebut dengan "a limited or framework of government with significant positive responsibilities".

Dari hasil analisisnya, peranan administrasi publik dalam masyarakat, adalah: Pertama, administrasi publik berperan menjamin pemerataan distribusi pendapatan nasional kepada kelompok masyarakat. Kedua, administrasi publik berperan melindungi hak -hak pribadi masyarakat atas pemilikan kekayaan, serta menjamin kebebasan bagi masyarakat untuk melaksanakan tanggung- jawab atas diri mereka sendiri dalam bidang kesehatan, pendidikan, dan pelayanan bagi kelompok masya- rakat lanjut usia. Ketiga, administrasi publik 'berperan melestarikan nilai- nilai tradisi masyarakat yang sangat bervariasi itu dari satu generasi kegenerasi berikutnya, serta memberikan jaminan dan dukungan sumber- sumber sehingga nilai-nilai tersebut mampu tumbuh dan berkembang sesuai tuntutan perubahan zaman, serta dapat terus hidup bersama secara damai, serasi dan selaras dengan budaya lain di lingkungannya.

Apabila kita simak, dari beberapa pemikiran dan pendapat di atas, tampaknya masih cukup relevan dengan kondisi perkembangan paradigma pembangunan di negara- negara dunia ketiga termasuk Indonesia. Namun demikian, kecenderungan yang jelas adalah pemerintahan nasional suatu bangsa terutama negara berkembang dalam era globalisasi, tantangannya tidak akan pernah terhindarkan dari kondisi ketergantungannya kepada negara -negara lain, ataupun institusi global lainnya yang berkepentingan terhadap keseimbangan dan ketahanan sistem ekonomi global.

Tantangan administrasi publik yang juga perlu mendapat perhatian adalah terkait dengan daya saing bangsa. Indikator daya saing dapat dilihat dari pendidikan, kesehatan dan kesejahteraan. Berdasarkan indikator utama (BPS: Indikator Kunci Utama, Edisi khusus, 2007), menunjukkan bahwa jumlah penduduk miskin tahun 2005 sebesar 35,1 juta. dan pada tahun 2006 meningkat menjadi 39.3 juta manusia. Angka ini diikuti angka pengangguran terbuka dan setengah mengangggur 39.38\% dari 222.192 juta penduduk. Di sektor pendidikan, persentase penduduk berumur 5 tahun ke atas pada tahun 2005, total di perkotaan (urban), 7\% tidak/belum sekolah, 25,60\% masih- sekolah, dan 67,40\% tidak sekolah lagi. Sedangkan di pedesaan (rural) 13,42 \% tidak/belum sekolah, 23,64 \% masih sekolah dan 62,94\% tidak sekolah lagi. Indikator pendidikan menjadi penting dalam konteks pembahasan kepemimpinan, sebab pada dasamya pendidikan merupakan instrumen utama dalam kerangka kaderisasi kepemimpinan suatu bangsa. Di beberapa negara maju

CC-BY-SA 4.o License, Copyright 2021, Public Inspiration, ISSN 2581-2378, E-ISSN 2580-5975 
seperti Singapura misalnya, para pemimpin yang sekarang memegang tampuk pemerintahan adalah hasil kaderisasi tahun 1960 dan 1970-an.

Selanjutnya, dilihat dari terbatasnya kesempatan kerja, menyebabkan angka pengangguran makin meningkat. Pada tahun 2005, angka pengangguran mencapai 10,26 persen dari total jumlah penduduk. Tampaknya pemerintah perlu upaya lebih serius dalam menangani masalah pengangguran. Kegagalan dalam penanganannya akan mengakibatkan angka pengangguran makin meningkat dan darnpak negatif sosial kemasyarakatan. Persoalan lain yang dihadapi dalam angkatan kerja adalah upah yang relatif kecil serta produktivitas yang rendah.

Dampak masih rendahnya pendidikan maupun ketenagakerjaan, menjadi tantangan yang cukup serius ditinjau dari administrasi publik. Berbagai upaya pemerintah melalui kebijakan publik telah diberlakukan, namun dalam implementasinya belum banyak menyentuh secara substansial. Bahkan program BLT (Bantuan Langsung Tunai) dalam kenyataannya menjadi "Bantuan Langsung Telas (habis)". Di sisi lain, usaha kecil dan menengah yang mencapai angka 99,9 persen belum mampu menggerakkan ekonomi kerakyatan, penyebabnya antara lain sulitnya mendapatkan pinjaman dari Bank dan kemampuan manajemen usaha (Kementerian Negara Koperasi dan UKM, 2007) Dampak rnasih rendahnya pendidikan maupun ketenagakerjaan, menjadi tantangan yang cukup serius ditinjau dari administrasi publik. Berbagai upaya pemerintah melalui kebijakan publik telah diberlakukan, namun dalam implementasinya belum banyak menyentuh secara substansial. Bahkan program BLT (Bantuan Langsung Tunai) dalam kenyataannya menjadi "Bantuan Langsung Telas (habis)". Di sisi lain, usaha kecil dan menengah yang mencapai angka 99,9 persen belum mampu menggerakkan ekonomi kerakyatan, periyebabnya antara lain sulitnya mendapatkan pinjaman dari Bank dan kemampuan manajemen usaha (Kementerian Negara Koperasi dan UKM, 2007).

Perkembangan administrasi publik juga berpengaruh terhadap pemerintahan wilayah (provinsi, kabupaten dan kotamadya) dalam bentuk peluang untuk membangun hubungan ekonomi langsung dengan perekonomian global. Sebagai gambaran, sejak diberlakukannya otonomi daerah, wilayah administratif Republik Indonesia bertambah menjadi 33 provinsi baru. Akibat pemekaran wilayah ini, jumlah wilayah administratif pada tingkat yang lebih rendah juga meningkat, masing-masing menjadi 349 kabupaten, 91 kotamadya, 5.641 kecamatan dan 71.555 desa (BPS, Statistik Indonesia, 2005/2006: xiii). Namun tambahan daerah administratif belum mampu mengurangi masalah sosial ekonomi dan peningkatan kualitas pelayanan kepada masyarakat.

Ulasan tersebut di atas menggambarkan bahwa tantangan adrninistrasi publik menjadi sangat kompleks, dan tentunya memerlukan suatu terobosan apabila kita menginginkan secepatnya keluar dari krisis multidimensi. Ditinjau dari perspektif administrasi publik, pada hakikatnya keberadaan suatu negara bangsa adalah demi peningkatan kesejahteraan seluruh warganya. Dikatakan demikian, oleh karena negara-negara di dunia pada umumnya didirikan sebagai "welfare state" terlepas dari ideologi dan sistem politik yang dianut. Untuk mencapai tujuan yang mulia tersebut, diperlukan berbagai jenis organisasi, yang tangguh dan handal, baik didalam maupun di luar lingkungan pemerintahan untuk menghadapi tantangan dengan intensitas yang berbeda-beda, yang pasti akan dihadapi di masa datang.

\section{Arah Perkembangan Administrasi Publik}

Dari uraian secara sekilas tentang tantangan administrasi publik, pertanyaan yang kemudian muncul adalah kemana arah perkembangan administrasi publik? Pada hakikatnya, setiap negara bangsa dalam Abad ke-21 dihadapkan pada kondisi lingkungan stratejik yang berbeda dengan Abad 20. Harapan-harapan besar terentang bagi setiap bangsa untuk memanfaatkan peluang peluang yang berkembang dalam tatanan ekonomi dunia di Abad ke21. Namun sayangnya, pada awal abad ini, berdasarkan hasil kajian dan data-data statistik sebagaimana secara sampel telah dikemukakan, Indonesia masih terpuruk dalam krisis multi 
dimensi. Penyebab kondisi tersebut juga dipengaruhi oleh perkembangan internasional, namun cukup banyak faktor penyebab mendasar bersumber dari dalam organisasi itu sendiri.

Di antara faktor penyebab terjadinya krisis multi dimensi, masalah yang sangat mendasar adalah terletak pada kelemahan dalam pengembangan "sistem dan proses adminisirasi publik". Salah satunya adalah rendahnya komitmen kepemimpinan aparatur negara, antara lain berupa penyimpangan terhadap berbagai dirnensi nilai yang seharusnya menjadi acuan perilaku individu dan institusi yang berperan dalam penyelenggaraan negara. Inkonsistensi perilaku individu dan kebijakan, menyebabkan nilai dan prinsip kepemerintahan yang baik dan sesungguhnya melekat atau merupakan bagian dari karakteristik sistem adrninistrasi negara menjadi terabaikan atau tidak sepenuhnya mendapatkan perhatian, sehingga sistem kelembagaan negara, dunia usaha, dan masyarakat bangsa menjadi rapuh.

Pernyataan tersebut di atas memunculkan pertanyaan yang sangat mendasar, benarkah bahwa Sistern Administrasi Negara yang merupakan bagian penting Ilmu Administrasi Publik terkandung nilai dan prinsip kepemerintahan yang baik (amanah)? Apabila jawabannya II ya" mengapa kepemerintahan yang baik tidak pemah terwujud secara semestinya sepanjang sejarah pemerintahan Indonesia Merdeka, padahal "Sistem Administrasi Negara Republik Indonesia" telah berkembang sejak Indonesia Merdeka. Berbagai permasalahan dan pertanyaan dapat muncul dan terus berkembang seiring dengan kompleksitas dan dinamika perkembangan permasalahan negara dan bangsa. Dalam hubungan itu, valid untuk mempertanyakan apakah peran dan manfaat Ilmu Administrasi Publik dalam menghadapi masalah-masalah bangsa tersebut. Pertanyaan yang kemudian berkembang adalah kembali pada validitas ke ilmuan dari Ilmu Adrninistrasi Publik. Dengan kata lain, dalam paradigma baru Ilmu Administrasi Publik dituntut untuk mengembangkan teorinya agar Ilmu Administrasi Publik dapat mempertahankan scientific validity dan policy relevance- nya. Secara lebih spesifik, perubahan konfigurasi tadi seharusnya memicu perkembangan teori-teori dalam Ilmu Administrasi Publik. Tetapi karena fenomena globalisasi dan Abad Ke-21 merupakan fenornena multifacet, maka varian teori administrasi publik yang berkembang untuk menjawab tantangan juga beraneka ragam. Sebagai contoh, dapat dikemukakan:

Pada dimensi ekonomi politik, globalisasi telah merubah hubungan antara negara (the state) dengan pasar (market). Pembangunan di banyak negara-negara dunia ketiga tidak lagi bersifat state led development, akan tetapi menjadi bersifat market driven development. Hal ini mendorong teori- teori tentang birokrasi yang merefleksikan enterprenuerial bureauc -racy (Mulyarto, 2003). Dari berbagai pendapat dan kajian para pakar, dapat disimpulkan bahwa entre- prenuerial bureaucracy dimaksud memiliki ciri-ciri, sebagai berikut; (1) bersifat sensisitf dan responsif terhadap peluang baru yang timbul di dalam pasar, khususnya sebagai akibat dari proses globalisasi, liberalisasi dan regionalisasi perdagangan; (2) mampu melepaskan diri dari rutinitas kerja yang terkait dengan fungsi instrumental birokrasi dan mampu melakukan terobosan (breakthrough) melalui pemikiran yang kreatif dan inovatif dalam rangka mengatasi sifat-sifat inertial kelambanan birokrasi; (3) mempunyai wawasan jauh ke depan (futuristic) dan melihat sesuatu persoalan dalam kaitannya dengan variabel-variabel yang lain (systemic); (4) jeli dan cermat terhadap adanya sumber-sumber potensial baik yang berasal dari dalam negeri maupun sumber eksternal (outsourcing); (5). Memiliki kemampuan mengkombinasikan berbagai sumber menjadi resource mix yang mempunyai efek sinergis yang berproduktivitas tinggi, dan (6) memiliki kemampuan untuk memanfaatkan sumber secara optimal dan menggeser pemanfaatan sumber bagi kegiatan yang berproduktivitas tinggi. Birokrasi yang enterpreneurial menurut (Propenko, 1991: 45) tidak puas dengan kondisi statis dan seringkali hams menciptakan destabilizing forces dalam rangka creative contructive equilibrium.

Dari segi dimensi sosial kultural, globalisasi mendorong terjadinya ams tenaga kerja 
yang melintasi batas-batas negara (cross-border human resource flow) yang mau tidak mau akan menimbulkan perbenturan budaya. Perusahaan-perusahaan joint venture akan makin bermunculan sebagai akibat proses globalisasi ini. Kenyataan ini mendorong pemikiran teoritis tentang manajemen di dalam organisasi multikultural karena proses globalisasi tidak akan sepenuhnya menimbulkan homogenitas global baik secara kultural maupun secara filsafati. Karenanya teori tentang cross-cultural management dan multicultural leadership merupakan salah satu tuntutan sebagai konsekwensi logis dari proses globalisasi ini. Keanekaragaman latar belakang budaya, baik domestik maupun international, akan menjadi motor penggerak kreativitas dari organisasi-organisasi multikultural yang timbul sebagai akibat proses globalisasi ini. Teori- teori administrasi yang memfokuskan perhatiannya pada multi-cultural administration atau multi-cultural management ini belum banyak berkembang.

Dilihat dari dimensi temporal, globalisasi mengakibatkan konfigurasi administrasi publik berkembang dengan cepat dan dinamis sehingga ketidakmampuan seorang administrator mengantisipasi perkembangan yang akan terjadi mengakibatkan ketertinggalan dari dinamika perubahan konfigurasi tadi. Oleh karena itu, wawasan futuristic merupakan salah satu kualitas yang dituntut oleh proses globalisasi tadi. Karenanya proses administrasi tidak seharusnya dilihat semata-mata dari perspektif waktu masa sekarang, akan tetapi hams mengantisipasi proses perubahan yang terjadi di masa depan. Hal ini mendorong kelahiran teori-teori administrasi publik yang berwawasan jauh ke depan. Salah satu manifestasi dari perkembangan dimaksud, adalah dikembangkannya teori-teori tentang forward focused organization (Harper, 2001: 291). Asumsi yang mendasari adalah perubahan-perubahan prinsipil yang seringkali terjadi secara cepat memerlukan kepemimpinan yang visioner, yang mampu melihat perubahan sebagai peluang dan bukan ancaman, mampu melihat kebutuhan akan perubahan pada saat posisinya di dalam dimensi temporal masih berada di dalam kekinian, dan mampu menciptakan iklim di mana bawahannya akan dapat menerima perubahan sebagai sesuatu yang wajar. Dengan kata lain, teori ini berpendapat bahwa diperlukan sosok kepemimpinan yang dapat membawa organisasi kepada perubahan, yang mampu menciptakan masa depan (future) bagi organisasi yang dipimpinnya. Meskipun teori -teori tentang future focused organization ini belurn sepenuhnya berkembang, namun hal ini merupakan tuntutan organisasi di dalam menyongsong proses globalisasi.

Dengan demikian, proses globalisasi tidak seharusnya diartikan secara sempit hanya dilihat dari segi ekonomi, akan tetapi juga mencakup penyebaran nilai-nilai politik yang dipandang berlaku universal, seperti penghormatan terhadap hak-hak azazi manusia, demokratisasi, nilai-nilai kepemerintahan yang baik, dan sebagainya. Hal ini merubah hubungan kekuasaan antara negara dan masyarakat sipil menuju hubungan yang lebih simetris antara negara dan masyarakat sipil. Lahirlah teori-teori yang bertujuan mencari kese - imbangan baru (rebalance) diantara struktur kekuasaan yang ada di dalam rnasyarakat dengan menjadikan tindakan dan kebijakan birokrasi lebih akuntabel, partisipatif dan iransparan, dengan meningkatkan kekuasaan masyarakat sipil di dalam memanage kepentingan mereka dan dengan menjadikan pasar/swasta (corporate bussiness) lebih mempunyai tanggung jawab sosial.

Dalam teori tersebut, fungsi birokrasi hams mampu menjembatani antara civil society yang merepresentasikan kepentingan- kepentingan khusus di dalam masyarakat, dengan the state yang merupakan representasi kepentingan umum. Tugas birokrasi adalah menciptakan enabling social setting bagi masyarakat sipil agar mereka dapat melakukan pernberdayaan diri (self-empowering). Teori-teori administrasi publik yang konvensional mungkin sekali belum mengakomodasikan perkembangan konfiguratif ini. Hal lain yang perlu diperhatikan, bahwa proses globalisasi menuntut perubahan mindset dan kemarnpuan yang oleh Moran dan Riesenberger (2003: 66), disebut sebagai global competencies. Menurut Bintoro Tjokroamidjojo (2006: 34), ketidakmampuan birokrat dan pilar-pilar kepemerintahan yang baik (good governance) untuk memahami konfigurasi baru tersebut akan menimbulkan

CC-BY-SA 4.o License, Copyright 2021, Public Inspiration, ISSN 2581-2378, E-ISSN 2580-5975 
capacity gap yang dapat mengakibatkan masing-masing pilar menjadi dysfunctional.

\section{Paradigma Baru Kepemimpinan}

Berdasarkan alur pernikiran, latar belakang tantangan dan arah perkembangan administrasi publik nampak talitemali (trace) antar fenomena, salah satu inti permsalahannya adalah faktor "paradigma baru kepemimpinan" yang diharapkan memiliki kemampuan memimpin organisasi Abad ke-21. Dari perspektif teoretis, para pakar administrasi publik sepakat bahwa kepemimpinan merupakan inti administrasi dan manajemen. Sebagai inti yang memiliki peran sentral, menunjukkan bahwa kepemimpinan didudukan pada tataran organisasi di posisi yang sangat stratejik. Para pemimpin dipercaya, mampu memandu perjalanan organisasi kearah tujuan yang telah ditentukan sebelumnya. Dalam berbagai kajian dan pengalaman empirik, membuktikan bahwa peran kepemimpinan organisasi menjadi penggerak, pengungkit, pendorong, pelindung, pelayan dan penanggungjawab berbagai aktivitas organisasional. Bahkan seperti telah dikemukakan, para pemimpin adalah manusia- manusia yang memiliki kekuatan, kecerdasan dan jumlahnya sedikit dan menentukan arah perjalanan sejarah suatu organisasi. Dengan kata lain, peranan tradisional pemimpin yang mencakup; pengendali, pemberi periniah, bertindak sebagai hakim, dan menjaga, sudah tidak sesuai lagi dengan tuntutan lingkungan internal maupun eksternal organisasi.

Atas dasar hal tersebut, pemikiran mengenai paradigma baru kepemimpinan aparatur negara pada hakikatnya beranjak dari pandangan bahwa pemirnpin publik harus mengenali secara tepat dan utuh baik mengenai dirinya maupun kondisi dan aspirasi masyarakat yang dipimpinnya, perkembangan dan permasalahan lingkungan stratejik yang dihadapi dalam berbagai bidang kehidupan serta paradigma dan sistem administrasi di mana ia berperan. Tanggungjawab pemimpin adalah memberikan jawaban secara arief dan bijak, efisien, dan produktif atas berbagai permasalahan dan tantangan yang dihadapi zamannya, yang dilakukan bersama dengan orang-orang yang dipimpinnya.

Untuk itu setiap pemimpin tidak hanya rnemenuhi kompetensi dan kualifikasi tertentu, lebih dari itu harus menjadi agen perubahan yang handal. Jika konfigurasi kepemimpinan terbangun dari tiga unsur yang interdependensial, yaitu pemimpin, kondisi masyarakat dan perkembangan lingkungan nasional dan internasional yang senantiasa mengalami perubahan, maka valid jika kita rnernpertanyakan kualifikasi dan kornpetensi kepemimpinan sebagai persyaratan kepemimpinan yang efektif, khusunya dalam menghadapi kompleksitas perkembangan dan dinamika perubahan Abad ke-21. Dalam hubungan itu, kita pun perlu mempertanyakan paradigma dan sistem administrasi publik yang relevan dan diperlukan untuk menghadapi berbagai permasalahan dan tantangan, baik internal maupun eksternal, ataupun untuk mewadahi interplay dan interdependensi yang terjadi dalam proses kepemimpinan dan perubahan.

Seorang pemimpin publik harus mampu melihat kehadiran dirinya dalam konteks yang luas dan dasar nilai-nilai yang dianut serta merupakan acuan hidup dan kehidupan masyarakat bangsanya. Pada tataran tertentu, ia harus dapat menangkap makna kehadirannya sebagai bagian dari sistem administrasi negara yang mendeterminasikan kompleksitas struktur dan dinamika proses kelembagaan masyarakat negara dan bangsa serta dalam hubungan antarbangsa, yang hakikinya merupakan wahana perjuangan bangsa dalam mewujudkan cita-cita dan tujuan negara.

Kompleksitas dan dinamika perkembangan lingkungan stratejik, pada tataran nasional ditandai oleh permasalahan dan tantangan yang multi dimensional, di bidang sosial, ekonomi, politik, kelembagaan, serta pertahanan dan keamanan, yang ditandai antara lain oleh lemahnya struktur dan daya saing perekonomian, penegakkan hukum, pelaksanaan otonomi dan desentralisasi, besarnya hutang luar negeri, tingkat kemiskinan dan pengangguran, demokratisasi, ancaman disintegrasi, serta daya saing kepemimpinan. Pada tataran internasional, terdapat perkiraan bahwa perkembangan lingkungan global ditandai 
situasi, kondisi, tantangan dan tuntutan yang makin kompleks, selalu berubah, penuh ketidakpastian, dan bahkan sering tidak ramah.

Perkembangan lingkungan stratejik tersebut, menuntut pemimpin dan kepemimpinan yang solid, handal, mampu mengantisipasi perkembangan ke depan, membangun visi, misi, dan strateji serta mengembangkan langkah-langkah kebijakan, sistem kelembagaan dan manajemen pemerintahan yang relevan dengan kompleksitas perkembangan, permasalahan dan tantangan yang dihadapi, baik pada tataran nasional maupun global.

Dalam kaitan hal tersebut, peran para pemimpin dalam memotivasi, menggerakkan, mendorong, memberikan inspirasi menjadi sangat penting. Peran kepemimpinan dalam menghadapi tantangan Abad ke-21, tidak hanya berada di puncak organisasi tetapi juga berada di bawah bersama-sama seluruh sumber daya organisasi bergerak maju. Sejalan dengan hal ini, Ann Howard (2006: 57) seorang Presiden Leadership Research Institute dan Konsultan. Senior dari International Development Dimensions mengemukakan, seorang pemimpin harus memiliki keterlibatan tinggi. Peranan yang membantu kepemimpinan dengan keterlibatan tinggi dirancang untuk suatu organisasi, dibangun untuk kecepatan, keluwesan, mutu, dan pelayanan, yang penting bagi persaingan global.

Dilihat dari perspektif kepemimpinan, ada sejumlah kiat yang ditawarkan para pakar, untuk menjawab tantangan administrasi publik bila kemauan untuk mengadakan perubahan didasari pada pikiran-pikiran yang mendukung prinsip gradual and peaceful changes, maka cara-cara transformasi dan penggantian (transplacement) harus dilakukan.

Secara kultural, peran dan teladan pemimpin masih sangat menentukan dalam proses perubahan. Dimanapun masyarakat kita masih sangat menghargai esensi seorang pemimpin. Pepatah "Raja adil raja disembah, Raja Lalim raja disanggah", nampaknya tetap dapat dijadikan rujukan para pemimpin kita. Kemudian, konsistensi dalam melakukan perubahan juga harus ditunjukkan oleh mereka (para pemimpin).

Sesuai dengan norma-norma demokratis, transparansi dan kompetensi hendaknya dijadikan pegangan juga di dalam melakukan fungsi yang terakhir ini. Unsur like and dislike harus dibuang jauh-jauh bila ingin melakukan pembaharuan. Dengan cara ini, political supports dan legitimasi seorang pemimpin akan terns dipertahankan.

Selain itu, pada tataran pemimpin negara (kepemimpinan aparatur negara), tingkah laku para pemimpin diharapkan menghargai prinsip- prinsip administrasi publik modern. Bila pada era Orde Baru stabilitas dijadikan paradigma dalam memerintah, tapi sekarang kemajemukan dan pelaksanaan check and balances harus dikembangkan di antara ketiga cabang kekuasaan yang ada (legislatif, eksekutif dan yudikatif). Hal tm mengandung konsekuensi perlunya membuat sebuah lembaga perwakilan rakyat yang lebih jelas fungsinya. Kecenderungan untuk membentuk sistem dua kamar (bikameral) dalam lembaga perwakilan rakyat yang mewakili suara pemilih wilayah akhirnya terwujud dengan dibentuknya Dewan Perwakilan Daerah (DPD).

Selanjutnya untuk mengurangi kekuasaan Presiden yang kerapkali dipersoalkan, dan tidak dipandang sebagai puncak piramida kekuasaan telah diwujudkan lewat pemilihan presiden secara langsung, demikian juga dengan pemimpin derahnya.

Namun demikian, dalam beberapa kasus kinerja para pemimpin belum sesuai harapan. Penyebabnya, tidak semua pemimpin yang rnencalonkan memiliki standar kualifikasi dan kompetensi yang dipersyaratkan, tetapi lebih pada dukungan politik.

Pada tataran aktor negara, pemerintah harus sungguh-sungguh melaksanakan "amanat penderitaan rakyat baru", yakni kesulitan ekonomi dan pemerataan pendapatan, kesehatan serta pendidikan. Sementara para anggota lembaga perwakilan rakyatnya harus berpikiran ke depan, tidak hanya membahas persoalan- persoalan politik kekinian (baca: kekuasaan), melainkan mengembangkan fungsi representasi, budgeting dan legislasi dalam arti yang luas. 
Siapapun yang duduk pada posisi yudikatif, sudah sepantasnya untuk secara obyektif dan jujur melakukan terobosan hukum yang mendukung penegakkan keadilan dan sistem hukum nasional yang lebih demokratis yang pada gilirannya akan mendorong terwujudnya kepemerintahan yang baik (good governance).

Bagi pemimpin masyarakat, berbagai rekayasa sosial hendaknya ditingkatkan untuk membangun sebuah masyarakat madani yang lebih mandiri dan tidak tergantung kepada negara. Partai politik dan berbagai kelompok penekan, hendaknya dapat menjadi fasilitator bagi pengembangan masyarakat madani. Partai politik mestinya tidak semata-mata dijadikan medium bagi mobilitas vertikal para aktivisnya, melainkan sungguh didorong untuk mengembangkan dua fungsi utamanya, yaitu inputs berupa artikulasi dan agregasi kepentingan, sosialisasi dan pendidikan politik rakyat, dan fungsi outputs-nya berupa keterlibatan dalam pembuatan keputusan serta pengawasan pelaksanaan kebijakan. Sejauh ini, nampaknya peran partai politik masih jauh dari fungsi tersebut, dan tertinggal di belakang ketimbang Kelompok Penekan ataupun organisasi kepentingan yang ada dalam masyarakat.

Terkait dengan hal-hal dimaksud, menurut Warren Bennis (1997: 251), tantangan pemimpin publik adalah kemampuannya untuk mengem- bangkan arsitektur sosial organisasi mereka, sehingga memiliki kemam- puan menciptakan modal intelektual. Apa yang harus dipelajari untuk dilakukan oleh para pemimpin adalah mendorong orang-orang yang amat cerdas dan kebanyakan memiliki ego serta motivasi tinggi untuk bekerja bersama dengan berhasil, dan memanfaatkan kreativitas mereka sendiri.

Dibandingkan dengan Abad ke- 21, bagi para pemimpin abad ke-20 dunia lebih linear, dimana berbagai organisasi bersifat hierarkhis dan birokratis. Dalam arti tertentu itu mirip dengan pemahaman awal mengenai komputer, di mana kita tinggal memasukkan semua informasi ke dalam sistem, lalu membiarkan komputer mengolah sendiri dan memberi pemecahan masalah. Pola pikir kuno dapat diringkaskan tiga kata; konirol, perintah dan ramalkan. Hal ini dapat berjalan di lingkungan yang stabil, di mana dalarn banyak hal kita dapat mengontrol, memerintah dan meramalkan. Namun apabila dihadapkan pada situasi yang terus berubah, pola tidak dapat berjalan.

Menurut Joy McFarland (2002: 34-35), pada era sekarang kepemimpinan diibaratkan sebagai mata uang. Pertanyaannya adalah bagaimana menginvestasikan? Untuk itu, kini saatnya berinvestasi dalam membangun masyarakat baru Abad ke-21. Kita perlu memulai suatu kampanye kepe-mimpinan dalam rangka pember-dayaan orang-orang dalam rangka membuat perbedaan. Dalam masa sekarang, administrasi publik juga dihadapkan pada kebutuhan yang mendesak akan berbagai strategi yang jelas, karena kalau tidak memiliki visi yang jelas mengenai cara kita menampilkan diri secara unik dan berbeda dari yang lain, kita akan ditelan hidup-hidup oleh persaingan yang makin sengit. Peringatan ini temyata benar dan kenyataan menunjukkan bahwa cukup banyak organisasi bisnis bahkan pemerintah mengalami kemunduran yang signifikan dan mengalami krisis multidimensi yang berkepanjangan.

Walaupun demikian, kepemimpinan tidak hanya dibutuhkan dalam kondisi krisis yang dialami oleh sebuah organisasi, tetapi dalam kondisi apapun. Hal ini membuktikan, keberadaan seorang pemimpin dalam setiap organisasi sangatlah penting. Lebih penting lagi pada era yang penuh ketidakpastian dan bergejolak, menuntut seorang pemimpin yang tidak hanya memiliki kapabilitas manajerial tetapi juga seorang pemimpin yang mampu mengarahkan orang lain untuk memimpin dirinya sendiri.

Tuntutannya adalah, tipe pemimpin yang dibutuhkan adalah pemimpin yang dapat memberdayakan (empower) orang lain. Pemimpin menjadi "super", karena memiliki kekuatan dan kearifan terhadap semua orang dengan membantu para anak buahnya untuk mampu melepaskan diri dari belenggu ketidakmampuan menyalurkan seluruh kemampuan dari pengikut dengan baik. 
Dengan demikian, para pemimpin yang dapat bertahan di abad sekarang ini, adalah jika mereka berkembang seiring perubahan waktu. Abad ini menuntut paradigma baru kepemimpinan, mengikuti puncak perubahan, bukan terombang-ambing dalam perubahan itu.

Para pakar memandang perubahan merupakan akibat dari globalisasi, persaingan, dan menurunnya tingkat hierarki. Mereka melihat bahwa para pemimpin bukan saja berada di puncak, melainkan juga berada di semua lapisan organisasi. Setiap orang dalam organisasi perlu menyumbangkan kreativitasnya dalam upaya pengembangan diri dan organisasi.

Kepemimpinan harus bersifat luas dan mendalam, menyebarke setiap fungsi dan departemen di semua tingkat. Pada Abad ke-21, juga dibutuhkan para pemimpin super (superleaders) yang membantu para pengikutnya menjadi pemimpin bagi dirinya sendiri, dan bukan mereka yang memerintah, karismatis, dan penguat tunggal.

Ronald R. Fogleman (dalam Shelton, 2002: 12) percaya, bahwa karena para pemimpin bekerja dengan sumber daya dasar yang sama, pemimpin yang baik dan atau buruk dibedakan oleh keberanian dan keteguhan mereka, kerangka kerja mereka dalam mengambil keputusan, kesetiaan dan 'komitmen mereka terhadap pengikutnya (rakyatnya), yang memiliki karakter dan kepemimpinan yang memiliki resonansi.

Dalam arena kepemimpinan, karakter memiliki nilai. Misi mulia seorang pemimpin tidak boleh dijadikan alasan untuk menghalalkan segala cara. Oleh karena itu menurut Bennis (200:23), pemimpin harus memiliki integritas. Ada tiga hal integritas yaitu; pengenalan diri, ketulusan, dan kedewasaan. Adapun kepemimpinan yang memiliki resonansi menurut Goleman, R. Boyatzis dan Annie McKee (2006: 4-5) adalah kepemimpinan yang cerdas secara emosi yang mampu menguatkan dan memperpanjang gema nada dan dampak emosi kepemimpinannya masuk dalam seluruh kalbu anggota organisasi.

Paradigma baru kepemimpinan dengan demikian, menuntut transformasi yang menyentuh berbagai dimensi kepemimpinan. Dalam kaitan ini, Warren Bennis (dalam Ken Shelton, 2002: 11), menyatakan bahwa para pemimpin hanya mungkin dapat bertahan di era sekarang ini, jika mereka berkembang semng perubahan waktu. Abad ke-21, menuntut paradigma kepemimpinan baru, yang mengikuti puncak perubahan, bukan terombangambing dalam perubahan. Manz dan P. Sims, Jr (J. Basuki, 2006: 14), menambahkan bahwa kepemimpinan super (Superleadership) bukanlah tipe mereka yang "memeriniah, karismatis, dan penguat tunggal", mereka adalah para pemimpin yang membantu para pengikutnya menjadi pemimpin bagi diri sendiri.

Kepemimpinan dengan paradigma baru adalah pemimpin yang terus belajar, memaksimalkan energi dan menguasai perasaan yang terdalam, kesederhanaan dan multi fokus. Oleh karena itu, dinyatakan bahwa kualitas menjadi penting dan kuantitas tidak lagi menjadi keunggulan bersaing. Penekanan paling utama untuk pemimpin masa depan adalah pemimpin yang selalu belajar baik melalui pendidikan formal maupun dari pengalaman dalam pekerjaan. Mencari pengetahuan dan menggali ilmu terus dilakukan bagi pemimpin masa depan, hal ini sangat penting sebab ilmu pengetahuan merupakan energi vital bagi setiap organisasi.

Peter M. Senge, dalam bukunya "Fifth Discipline" (1995: 76) menge- mukakan, kepemimpinan dalam organisasi pembelajar berpusat pada tugas yang lebih penting dan tajam, Dalam organisasi pembelajar, pemimpin adalah pembuat rancang bangun, pelayan dan guru. Mereka bertanggung jawab untuk mem- bangun organisasi, dimana orang secara berkesinambungan mening- katkan kemampuannya untuk mengetahui kompleksitas, memperoleh visi yang jernih, memperbaiki model mental bersama, dan berarti mereka bertanggungjawab untuk belajar. Pandangan baru ini sangat vital dan penting untuk membangun paradigma baru kepemimpinan Kemudian dikemukakan, bahwa fungsi paling kritis dari kepemimpinan adalah membuat desain. Sebab pekerjaan mendesain merupakan 
sebuah tugas yang menyeluruh. Hal ini berarti seorang pemimpin dari organisasi belajar adalah mengintegrasikan visi, sistem, nilai, berpikir sistem, dan model mental atau lebih luas lagi mengintegrasikan keseluruhan disiplin belajar. Selain sebagai pendesain pemimpin juga penolong dan sebagai guru, serta harus kreatif. Dengan demikian, berpikir sistem, keahlian pribadi, model mental, visi dan organisasi pembelajar, kesemuanya dikenal sebagai disiplin kepemim- pinan. Kesemua orang yang terlibat dari area ini akan menjadi pemimpin netral dari organisasi yang belajar Dalam kaitan masalah sosial kemasyarakatan dengan kepemimpinan, salah satu prestasi yang cukup menonjol dari sosiologi modern adalah perkembangan dari teori peran (role theory). Dikemukakan, setiap anggota suatu masyarakat menempati status posisi tertentu, demikian juga halnya dengan individu diharapkan memainkan peran tertentu. Dengan demikian kepemimpinan dapat dipandang sebagai suatu aspek dalam diferensiasi peran. Ini berarti bahwa kepemimpinan dapat dikonsepsikan sebagai suatu interaksi antara individu dengan anggota kelompoknya.

Apabila dicermati secara seksama, dari sisi teori kepemimpinan apa yang dikemukakan para pakar, bahwa teori-teori kepemimpinan mencoba menerangkan dua hal yaitu, faktor-faktor yang terlibat dalam pemunculan kepemimpinan dan sifat dasar dari kepemimpinan. Penelitian tentang dua masalah iru lebih memuaskan daripada teorinya itu sendiri. Namun bagaimanapun teori- teori kepemimpinan cukup menarik, karena teori banyak membantu dalam mendefinisikan dan menentukan masalah-masalah penelitian.

Dari penelusuran literatur tentang kepemimpinan, teori kepemimpinan banyak dipengamhi oleh penelitian Calton (1879) tentang latar belakang tokoh terkemuka yang mencoba menerangkan kepemimpinan berdasarkan warisan. Beberapa penelitian lanjutan, mengemukakan individu- individu dalam setiap masyarakat memiliki tingkatan yang berbeda dalam inteligensi, energi, dan kekuatan moral serta mereka selalu dipimpin oleh individu yang benar- benar superior.

Perkembangan selanjutnya, beberapa ahli teori mengembangkan pandangan kemunculan pemimpin besar adalah hasil dari waktu, tempat dan situasi sesaat. Dua hipotesis yang dikembangkan tentang kepemimpinan, yaitu (1) kualitas pemimpin dan kepemimpinan yang tergantung kepada situasi kelompok, dan (2) kualitas individu dalam mengatasi. situasi sesaat merupakan hasil kepemimpinan terdahulu yang berhasil dalam mengatasi situasi yang sama (Hocking dan Boggardus, 1994: 313-334).

Dua teori yaitu Teori Orang-Orang Terkemuka dan Teori Situasional, berusaha menerangkan kepemimpinan sebagai efek dari kekuatan tunggal. Efek interaktif antara faktor individu dengan faktor situasi tampaknya kurang mendapat perhatian. Untuk itu, penelitian tentang kepemimpinan hams juga termasuk: (1) sifat-sifat efektif, intelektual dan tindakan individu, dan (2) kondisi khusus individu didalam pelaksanaannya. Pendapat lain mengemukakan, untuk mengerti kepemimpinan perhatian hams diarahkan kepada (1) sifat dan motif pemimpin sebagai manusia biasa, (2) membayangkan bahwa terdapat sekelompok orang yang dia pimpin dan motifnya mengikutinya, (3) penampilan peran hams dimainkan sebagai pemimpin, dan (4) kaitan kelembagaan melibatkan pemimpin dan pengikutnya.

Pendapat tersebut apabila diperhatikan dapat dikategorikan sebagai teori kepemimpinan dengan sudut pandang II Personal-Situasional", Hal ini karena, pandangannya tidak hanya pada masalah situasi yang ada, tetapi juga dilihat interaksi antar individu maupun antar pimpinan dengan kelompoknya. Teori kepemimpinan yang dikembangkan mengikuti tiga teori di atas, adalah Teori lnteraksi Harapan: Teori ini mengembangkan tentang peran kepemimpinan dengan menggunakan tiga variabel dasar yaitu; tindakan, interaksi, dan sentimen. Asumsinya, bahwa peningkatan frekuensi interaksi dan partisipasi sangat berkaitan dengan peningkatan sentimen atau perasaan senang dan kejelasan dari norma kelompok. Makin tinggi kedudukan individu dalam kelompok, maka aktivitasnya lebih sesuai dengan norma kelompok, interaksinya meluas, dan banyak anggota kelompok yang berhasil diajak berinteraksi. 
Pada tahun 1957 Stogdill mengembangkan Teori Harapan- Reinforcement untuk mencapai peran. Dikemukakan, interaksi antar anggota dalam pelaksanaan tugas akan lebih menguatkan harapan untuk tetap berinteraksi. Jadi, peran individu ditentukan oleh harapan bersama yang dikaitkan dengan penampilan dan interaksi yang dilakukan.

Inti kepemimpinan dapat dilihat dari usaha anggota untuk merubah motivasi anggota lain agar perilakunya ikut berubah. Motivasi dirubah dengan melalui perubahan harapan tentang hadiah dan hukuman. Perubahan tingkahlaku anggota kelompok yang terjadi, dimaksudkan untuk mendapatkan hadiah , atas kinerjanya. Dengan demikian, nilai seorang pemimpin atau manajer tergantung dari kemampuannya menciptakan hara- pan akan pujian atau hadiah.

Atas dasar teori diatas, House pada tahun 1970 mengembangkan Teori Kepemimpinan yang Motivasional. Fungsi motivasi menurut teori ini untuk meningkatkan asosiasi antara cara-cara tertentu yang bernilai positif dalam mencapai tujuan dengan tingkahlaku yang diharapkan dan meningkatkan penghargaan bawahan akan pekerjaan yang mengarah pada tujuan. Pada tahun yang sama Fiedler mengembangkan Teori Kepemimpinan yang Efektif. Dikemukakan, efektivitas pola tingkahlaku pemimpin tergantung dari hasil yang ditentukan oleh situasi tertentu. Pemimpin yang memiliki orientasi kerja cenderung lebih efektif dalam berbagai situasi. Makin sosiabel interaksi kesesuaian pemimpin, tingkat efektivitas kepemimpinan makin tinggi.

Teori kepemimpinan berikutnya adalah Teori Humanistik dengan para pelopor Argryris, Blake dan Mouton, Rensis Likert, dan Douglas McGregor. Teori ini secara umum berpendapat, secara alamiah manusia merupakan "motivated organism". Organisasi memiliki struktur dan sistem kontrol tertentu. Kepemim- pinan berfungsi memodifikasi organisasi agar individu bebas untuk merealisasikan potensi motivasinya dalam memenuhi kebutuhannya dan pada waktu yang sama sejalan dengan arah tujuan kelompok. Apabila dicermati, didalam Teori Humanisiik, terdapat tiga variabel pokok, yaitu (1) kepemimpinan yang sesuai dan memperhatikan hati nurani anggota dengan segenap harapan, kebutuhan, dan kemam- puannya, (2) organisasi yang disusun dengan baik agar tetap relevan dengan kepentingan anggota disamping kepentingan organisasi secara keseluruhan, dan (3) interaksi yang akrab dan harmonis antara pimpinan dengan anggota untuk menggalang persatuan dan kesatuan serta hidup damai bersama-sama. (Blanchard, Zigarmi, \& Drea, 2001), bahkan menyatakan, kepemim- pinan bukanlah sesuatu yang Anda lakukan terhadap orang lain, melainkan sesuatu yang Anda lakukan bersama dengan orang lain.

Teori kepemimpinan lain, yang perlu dikemukakan adalah Teori Perilaku Kepemimpinan. Teori ini menekankan pada apa yang dilakukan oleh seorang pemimpin. Dikemukakan, terdapat perilaku yang membedakan pemimpin dari yang bukan pemimpin. Jika suatu penelitian berhasil menemukan perilaku khas yang menunjukkan keberhasilan seorang pemimpin, maka implikasinya ialah seseorang pada dasarnya dapat dididik dan dilatih untuk menjadi seorang pemimpin yang efektif. Teori ini sekaligus menjawab pendapat, pemimpin itu ada bukan hanya dilahirkan untuk menjadi pemimpin tetapi juga dapat muncul sebagai hasil dari suatu proses belajar. Hasil penelitian penulis tahun 2002 yang melibatkan 500 manajer madya dilingkungan aparatur pemerintah pusat dan daerah yang telah mengikuti pendidikan dan pelatihan kepemimpinan, membuktikan bahwa terjadi perubahan perilaku yang cukup signifikan sebagai pengaruh dari variabel pendidikan dan pelatihan (Basuki, 2002).

Selain teori-teori kepemimpinan yang telah dikemukakan, dalam perkembangan yang akhir-akhir ini mendapat perhatian para pakar maupun praktisi, yaitu, pola kepemimpinan transformasional, kepemimpinan transaksional, dan kepemimpinan primal. Pola kepemimpinan trasformasional dan transaksional, adalah berdasarkan hasil kajian seorang ilmuwan di bidang politik yang bernama James McGregor Burns (1978) dalam bukunya yang berjudul "Leadership". Selanjutnya Bass (1985) meneliti clan mengkaji lebih dalam, mengenai kedua pola kepemimpinan dan kemudian mengumumkan secara resmi sebagai

CC-BY-SA 4.o License, Copyright 2021, Public Inspiration, ISSN 2581-2378, E-ISSN 2580-5975 
teori, lengkap dengan model dan pengukurannya. Kepemimpinan primal dikembang- kan oleh Goleman, Boyatzis dan McKee (2002) dalam karyanya "Primal Leadership: Realizing the Power of Emotional Intelligence", yang ide dasamya dari David McClelland.

\section{Kepemimpinan Transformasional}

Kepemimpinan transformasional hakikatnya, menunjuk pada proses membangun komitmen terhadap sasaran organisasi dan memberi kepercayaan kepada para pengikut untuk mencapai sasaran-sasaran tersebut. Beberapa teori kepemim- pinan transformasional mempelajari juga bagaimana para pemimpin mengubah budaya dan struktur organisasi agar lebih konsisten dengan strategi manajemen untuk mencapai sasaran organisasional.

Seperti telah dikemukakan, konsep awal tentang kepemimpinan transformasional telah diformulasi oleh Burns (1978) dari penelitian deskriptif mengenai pemimpin- pemimpin politik. Burns, menjelaskan bahwa kepemimpinan transfer- masional sebagai proses "para pemimpin dan pengikut saling menaikkan diri ke tingkat moralitas dan motivasi yang lebih tinggi", seperti kemerdekaan, keadilan, dan kemanusiaan, clan bukan di dasarkan atas emosi, seperti keserakahan, kecemburuan sosial, atau kebencian. Games McGregor Burns, 1978: 20).

Secara konsep, kepemimpinan transformasional di definisikan (Bass, 1985, 1993: 541554), sebagai kemampuan pemimpin mengubah lingkungan kerja, motivasi kerja, dan pola kerja, dan nilai-nilai kerja yang dipersepsikan bawahan sehingga mereka lebih mampu mengopti- malkan kinerja untuk mencapai tujuan organisasi. Ini berarti bahwa sebuah proses transformasional terjadi dalam hubungan kepemimpinan manakala pemimpin membangun kesadaran bawahan tentang pentingnya nilai kerja, memperluas dan meningkatkan kebutuhan yang melampaui minat pribadi serta mendorong perubahan tersebut ke arah kepentingan bersama termasuk kepentingan organisasi.

Dengan cara demikian, antar pimpinan dan bawahan terjadi kesamaan persepsi dengan tujuan dapat mengoptimalkan usaha mereka ke arah tujuan yang ingin dicapai organisasi. Dengan cara ini, diharapkan akan tumbuh keperca- yaan, kebanggaan, komitmen, rasa hormat, dan loyal kepada atasan sehingga mereka mampu mengoptimalkan usaha dan kinerja mereka lebih baik dari biasanya. Ringkasnya, pemimpin transformasional berupaya melakukan transforming of visionary menjadi visi bersama sehingga mereka (bawahan plus pemimpin) bekerja untuk mewujudkan visi menjadi kenyataan. Dengan kata lain, proses transformasional dapat terlihat melalui sejumlah perilaku kepemimpinan seperti attributed charisma, idealized influence, inspirational motivation, intelectual stimulation, dan individualized consideration.

Attributed charisma. Bahwa kharisma secara tradisional dipandang sebagai hal yang bersifat inheren dan hanya dimiliki oleh pemimpin- pemimpin kelas dunia. Penelitian membuktikan, bahwa kharisma bisa saja dimiliki oleh pimpinan di level bawah dari sebuah organisasi. Pemimpin yang memiliki ciri tersebut, memperlihatkan visi, kemampuan, dan keahliannya, serta tindakan yang lebih mendahulukan kepen-tingan organisasi dan kepentingan orang lain (masyarakat) daripada kepentingan pribadi. Karena itu, pemimpin kharismatik dijadikan suri tauladan, idola, dan model panutan oleh bawahannya.

Idealized influence. Pemimpin tipe ini berupaya memperngaruhi bawahannya melalui komunikasi langsung dengan menekankan pentingnya nilai - nilai, asumsi - asumsi, komitmendan keyakinan, serta memiliki tekad untuk mencapai tujuan dengan senantiasa mempertimbangkan akibat - akibat moral dan etika dari setiap keputusan yang dibuat. Ia memperlihatkan kepercayaan pada cita - cita keyakinan, dan nilai-nilai hidupnya. Dampaknya adalah dikagumi, dipercaya, dihargai, dan bawahan berusaha mengidentikkan diri dengannya. Hal ini disebabkan perilaku yang menomor satukan kebutuhan bawahan, membagi resiko dengan bawahan secara konsisten, dan menghindari penggunaan kuasa untuk kepentingan pribadi. Dengan demikian, bawahan bertekad dan termotivasi untuk mengoptimalkan usaha clan bekerja ke tujuan bersama. 
Inspirational motivation. Pemimpin transformasional bertindak dengan cara memotivasi dan memberikan inspirasi kepada bawahan melalui pemberian arti dan tantangan terhadap tugas bawahan. Bawahan diberi untuk berpartisipasi secara optimal dalam hal gagasan- gagasan, memberi visi mengenai keadaan organisasi masa depan yang menjanjikan harapan yang jelas dan transparan. Pengaruhnya diharapkan dapat meningkatkan semangat kelompok, antusiasisme dan optimisme dikobarkan sehingga harapan- harapan itu menjadi penting dan bernilai bagi mereka clan perlu di realisasikan melalui komitmen yang tinggi.

Intellectual stimulation. Bahwa pemimpin mendorong bawahan untuk memikirkan kembali cara kerja baru dalam menyelesaikan tugasnya. Pengaruhnya diharapkan, bawahan merasa pimpinan menerima clan mendukung mereka untuk memikirkan cara-cara kerja mereka, mencari cara-cara baru dalam menyelesaikan tugas, dan merasa menemukan caracara kerja baru dalam mempercepat tugas-tugas mereka. Pengaruh positif lebih jauh adalah menimbulkan semangat belajar yang tinggi (oleh Peter Senge, hal ini disebut sebagai "learning organization.

Individualized consideration. Pimpinan memberikan perhatian pribadi kepada bawahannya, seperti memperlakukan mereka sebagai pribadi yang utuh clan menghargai sikap peduli mereka terhadap organisasi. Pengaruh terhadap bawahan antara lain, merasa diperhatian dan diperlakukan manusiawi dari atasannya.

Kelima perilaku tersebut diharapkan mampu berinteraksi mempengaruhi terjadinya perubahan perilaku bawahan untuk mengoptimalkan usaha dan performance kerja yang lebih memuaskan ke arah tercapainya visi dan misi organisasi.

Meskipun masih banyak yang hams dikaji tentang kepemirnpinan transformasional, namun terdapat cukup bukti dari hasil-hasil berbagai jenis penelitian empms untuk mengusulkan beberapa pedoman sementara bagi para pemimpin yang mencoba untuk mentransformasikan organisasinya serta budayanya, dan bagi para pemimpin yang ingin memperkuat budaya yang ada dari suatu organisasi.

\section{Kepemimpinan Transaksional}

Pengertian kepemimpinan transaksional merupakan salah satu gaya kepemimpinan yang intinya menekankan transaksi di antara pemimpin dan bawahan. Kepemimpinan transaksional memungkinkan pemimpin memotivasi dan mempengaruhi bawahan dengan cara mempertukarkan reward dengan kinerja tertentu. Artinya, dalam sebuah transaksi bawahan dijanjikan untuk diberi reward bila bawahan mampu menyelesaikan tugasnya sesuai dengan kesepakatan yang telah dibuat bersama.

Alasan tersebut mendorong Burns untuk mendefinisikan kepemimpinan transaksional sebagai bentuk hubungan yang mempertukarkan jabatan atau tugas tertentu jika bawahan mampu menyelesaikan dengan baik tugas tersebut. Jadi, kepemimpinan transaksional menekankan proses hubungan pertukaran yang bernilai ekonomis untuk memenuhi kebutuhan fisiologis dan psikologis sesuai dengan kontrak yang telah mereka setujui bersama.

Menurut Bass (1985), sejumlah langkah dalam proses transaksional yakni; memperkenalkan apa yang diinginkan bawahan dari pekerjaannya dan mencoba memikirkan apa yang akan diperoleh bawahan jika hasil kerjanya sesuai dengan transaksi. Pemimpin menjanjikan imbalan bagi usaha yang dicapai, dan pemimpin tanggap terhadap minat pribadi bawahan bila ia merasa puas dengan kinerjanya. Dengan demikian, proses kepemimpinan transaksional dapat ditunjukkan melalui sejumlah dimensi perilaku kepemimpinan, yakni; contingent reward, active management by exception, dan passive management by exception. Perilaku contingent reward terjadi apabila pimpinan menawarkan dan menyediakan sejumlah imbalan jika hasil kerja bawahan memenuhi kesepakatan. Active management by exception, terjadi jika pimpinan menetapkan sejumlah aturan yang perlu 
ditaati dan secara ketat ia melakukan kontrol agar bawahan terhindar dari berbagai kesalahan, kegagalan, dan melakukan intervensi dan koreksi untuk perbaikan. Sebaliknya, passive management by exception, memungkinkan pemimpin hanya dapat melakukan intervensi dan koreksi apabila masalahnya makin memburuk atau bertambah serius.

\section{Kepemimpinan Primal}

Pada dasarnya, kepemimpinan primal atau yang utama adalah kepemimpinan yang memiliki resonansi. (Goleman, et al., 2006). Resonansi adalah penguatan atau pemanjangan suara melalui pemantulan atau melalui getaran yang selaras. Analogi getaran yang selaras untuk manusia terjadi apabila dua orang secara emosional berada di panjang gelombang yang sama. Salah satu tanda pemimpin yang resonan adalah adanya sekelompok pengikut yang bervibrasi dengan energi semangat dan antusiasisme pemimpin. Ciri primal leadership adalah kepemim- pinan yang memiliki resonansi yang berfungsi menguatkan dan memperpanjang nada dampak emosi kepemimpinan. Makin tinggi tingkat resonansi, makin sedikit suara gerak statis di dalam interaksi mereka. Resonansi pada dasarnya dapat mengurangi gangguan suara pada suatu sistem.

Suatu mantra bisnis menyatakan, "suatu tim berarti lebih banyak sinyal, lebih sedikit gangguan suara". Perekat yang melekatkan orang- orang di dalam sebuah tim dan yang mengikat orang kepada sebuah organisasi adalah emosi yang mereka rasakan. Seberapa baik pemimpin mengelola dan mengarahkan perasaan-perasaan itu, untuk membantu kelompok mencapai tujuannya akan sangat tergantung pada tingkat kecerdasan emosinya. Bagi pemimpin yang cerdas secara emosi, resonansi terjadi secara alamiah. Gairah dan energi antusias mereka akan menggema atau beresonansi keseluruh kelompok.

Meskipun demikian, jika perlu pemimpin seperti ini kadang-kadang bisa memproyeksikan suatu suasana hati yang serius dengan suasana emosi yang dirasakan oleh orang- orang yang dipimpinnya. Dibawah bimbingan pemimpin yang cerdas secara emosi, anggota organisasi akan merasakan tingkat kenyamanan yang saling menguntungkan. Mereka saling membagi ide, clan saling belajar satu sama lain, membuat keputusan bersama dan menyelesaikan tugas bersama, Mereka membentuk ikatan emosi yang membantu mereka untuk tetap terfokus, bahkan di tengah-tengah perubahan besar clan ketidakpastian, Keterikatan emosi juga membuat pekerjaan terasa lebih bermakna.

Disisi lain, jika pemimpin tidak berresonansi bisa saja orang- orang/pegawai hanya melakukan pekerjaan "cukup baik" tetapi tidak memberikan "yang terbaik". Tanpa hati yang memadai seorang pemimpin mampu "mengelola" tetapi tidak memimpin. Dengan demikian resonansi bukan hanya berakar pada suasana hati yang baik atau kemampuan pernimpin untuk mengatakan sesuatu hal dengan benar, tetapi juga pada sekumpulan kegiatan terkordinasi yang tercakup dalam gaya kepemimpinan tertentu. Secara tipikal pemimpin terbaik dan terefektif dan bertindak berdasarkan salah satu dari enam pendekatan kepem.impinan dan dengan terampil mengganti gaya. Enam gaya ini, yaitu visioner, pembimbing, afiliatif, demokratis, penentu kecepatan, dan gaya memerintah.

\section{Kepemimpinan Berbasis Pelayanan}

Dalam konteks administrasi publik, paradigma baru kepemimpinan aparatur negara yang perlu dikembangkan adalah kepemimpinan berdasarkan pelayanan. Mengapa pelayanan yang menjadi pertimbangan sebagai dasar paradigma baru kepemimpinan aparatur negara? Ada beberapa pertimbangan, yaitu:

Pertama, bahwa pelayanan publik selama ini menjadi ranah dimana negara yang diwakili oleh pemerintah berinteraksi dengan lembaga-lembaga non-pemerintah. Maknanya, buruknya praktik governance sebagai akibat kepemimpinan aparatur negara dalam penyelenggaraan pelayanan publik, sangat dirasakan oleh warga dan masyarakat luas. Ini berarti, jika terjadi perubahan yang signifikan pada ranah kepemimpinan yang berbasis pelayanan publik dengan sendirinya dapat dirasakan manfaatnya secara langsung oleh warga 
dan masyarakat luas. Dengan menjadikan pelayanan publik sebagai nilai dan jiwa kepemimpinan aparatur negara, maka diharapkan good governance akan secepatnya terwujud dan toleransi terhadap bad governance akan dapat dihentikan.

Kedua, bahwa salah satu makna penting dari governance yang membedakan dengan government adalah keterlibatan aktor-aktor di luar negara dalam merespon masalahmasalah publik. Governance lebih luas government karena dalam praktik governance melibatkan unsur- unsur masyarakat sipil dan mekanisme pasar. Selain itu, mewujudkan nilai-nilai yang selama ini mencirikan praktik good governance seperti efisien, non diskriminatif, berkeadilan, berdaya tanggap tinggi, dan mem.iliki akuntabilitas tinggi dengan mudah dikembangkan parameternya di dalam ranah pelayanan publik.

Ketiga, pelayanan publik melibatkan kepentingan semua unsur governance. Pemerintah sebagai representasi Negara, masyarakat sipil, dan mekanisme pasar memiliki kepentingan dan keterlibatan yang tinggi dalam ranah ini. Pelayanan publik memiliki high stake dan menjadi pertaruhan yang penting bagi ketiga unsur governance, karena baik buruknya praktik pelayanan publik sangat berpengaruh terhadap ketiganya.

Nasib sebuah pemerintahan, baik pusat maupun daerah, akan sangat dipengaruhi oleh keberhasilan para pemimpin dalam mewujudkan pelayanan publik. Keberhasilan sebuah rezim dan penguasa dalam membangun legitimasi kekuasaan sering dipengaruhi oleh kemampuan mereka dalam menyelnggarakan pelayanan publik yang baik dan memuaskan masyarakat.

Dengan memperhatikan berbagai hal di atas, para pimpinan di jajaran aparatur negara memiliki kepentingan untuk melakukan pembaharuan dalam praktik penyelenggaraan pelayanan publik. Nasib mereka, apakah dapat mempertahankan jabatannya atau tidak dipengaruhi kualitas pelayanan publik yang diberikan. Pertimbangan tersebut memperkuat niat membangun paradigma baru kepemimpinan yang berbasis pelayanan. Pelayanan sebagai sebuah konsep dasar paradigma baru kepemimpin, berangkat dari pemikiran bahwa, nilai dasar dari ajaran administrasi publik adalah "memberikan pelayanan kepada masyarakat tanpa membedakan siapa yang dilayani".

Melayani bermakna memberikan sesuatu jasa atau dalam bentuk lain secara ikhlas kepada orang lain (masyarakat) atau pelayanan berdasarkan hati nurani. Sikap ikhlas menuntut suatu komitmen yang kuat terhadap diri sendiri, institusi dan masyarakat yang dilayani serta pengorbanan. Komitmen bermakna sikap keberpihakan yang tinggi terhadap masyarakat yang dilayani. Sebagai sebuah proses, komitmen menuntut konsistensi dari para pemimpin. Sikap ini menjadi penting, karena konsistensi akan memberikan kenyamanan dan ketenangan serta keamanan bagi masyarakat. Sedangkan sikap pengorbanan menunjuk pada sikap menempatkan kepentingan orang lain (masyarakat yang dilayani) dibandingkan dengan kepentingan pribadi atau golongan/ kelompoknya.

Selain nilai-nilai dasar tersebut, nilai-nilai kepemimpinan transformasional, transaksasional dan kepemimpinan primal yang berbasis resonansi, juga merupakan indikator-indikator yang dimasukkan dalam mengukur kepemimpinan berbasis pelayanan. Berdasarkan hasil kajian dan pengalaman empirik, membuktikan bahwa organisasiorganisasi yang mendasarkan diri pada konsep pelayanan akan lebih langgeng dibandingkan dengan pendekatan lain.

Pasaruraman, Heskett, Groon-ros, Normann dan para pakar service management lainnya, yang mengembangkan model kualitas pelayanan (dalam Jan Hendrik Peters, 2006), menemukan bahwa faktor kepemim- pinan merupakan faktor yang sangat dominan dalam manajemen pelayanan. Dari konsep-konsep yang dikembangkan, keterlibatan para pemimpin sangat tinggi clan menentukan keberhasilan pelayanan yang dilakukan organisasi. Bahkan dalam model pelayanan yang dikembangkannya, secara tegas menempatkan kepemimpinan sebagai faktor utama dalam kualitas manajemen pelayanan. Kajian Pusat Studi Kependudukan dan Kebijakan UGM (2000), dan hasil kajian Lembaga Administrasi 
Negara $(2005,2006)$, walaupun secara eksplisit tidak dikemukakan namun hasilnya menunjukkan bahwa faktok kepentingan aparatur pemerintah menjadi variabel yang perlu diperhitungkan dalam pelayanan.

Pada tingkat lokal daerah, memperlihatkan bahwa daerah- daerah yang unggul dan berkembang pesat, karena daerah tersebut dipimpin oleh pemimpin yang memiliki kecerdasan pelayanan yang prima. Beberapa daerah yang dapat dikemukakan antara lain, Provinsi Gorontalo, Kabupaten Sragen, Kabupaten Solak, Kabupaten Karangayar, Kotamadya Tarakan, dan Kabupaten [embrana, dan daerah lainnya dengan ciri khas jenis pelayanan masing- masing daerah. Kemajuan yang dicapai masing-masing daerah apabila dicermati lebih disebabkan peran kepemimpinan pelayanan.

Pertanyaan yang kemudian muncul adalah bagaimana kalau terjadi penggantian kepemimpinan? Apakah pemimpin berikutnya minimal sama atau lebih baik masih belum dapat dijawab. Hal ini oleh karena sis tem politik kita menghendaki hanya paling banyak 2 (dua) kali masa jabatan untuk Bupati/Walikota dan Gubemur. Padahal untuk membangun suatu daerah tidak cukup dalam 10 tahun. Lebih dari itu, pendekatan yang digunakan dalam memilih pimpinan daerah adalah pada pendekatan kekuasaan.

Pada tingkat nasional, kepemimpinan Bung Karno dan Bung Hatta dan para pemimpin nasional lainnya mampu memotivasi, menggerakkan seluruh kekuatan bangsa Indonesia untuk merdeka, karena dilandasi sikap ikhlas berkorban untuk kepentingan yang lebih besar. Demikian juga kepemimpinan orde berikutnya yang dengan kelebihannya telah membawa perubahan besar kemajuan bangsa Indonesia. Hanya memang disayangkan, antar periode kepemimpinan sering ditemukan inkonsistensi kebijakan, sehingga rakyatlah yang harus menanggung akibatnya, Kerusakan sumber daya alam, rendahnya daya saing sumber daya manusia Indonesia lebih sebagai akibat inkosistensi kebijakan, dan lebih dari itu masih rendahnya kepemimpinan berbasis pelayanan yang dimiliki para pemimpin. Kepemimpinan berbasis pelayanan hakikatnya adalah sikap kepemimpinan yang selalu berpihak kepada kepentingan masyarakat. Kemenangan beberapa Gubernur atau Bupati yang mencalonkan kembali dan mendapat kemenangan mutlak, lebih disebabkan kualitas kepemimpinan pelayanan yang dinilai sangat baik oleh masyarakatnya.

Konsep kepemimpinan berbasis pelayanan menjadi sangat penting, sebagai konsekuensi logis dalam sistem demokrasi, dimana rakyat atau masyarakat adalah yang berkuasa. Dalam konsep demokrasi, masyarakat bukan didudukan sebagai obyek kekuasaan tetapi sebagai subyek dan sekaligus obyek penyelenggaraan pemerintahan negara. Hal ini bermakna sumber kekuasaan berada di tangan masyarakat. Kepemimpinan dalam sistem politik demokratis, hakikatnya adalah kepemimpinan yang memiliki kemampuan partisipatif, kecerdasan multikultural dan sosial clan bahkan kecerdasan spiritual. Kemampuan partisipatif dimaknai, sebagai sikap kepemimpinan yang selalu mendengar keluhan dan kebutuhan masyarakat dan bukan hanya mau didengar saja. Kecerdasan multikultural sebagai konsep dasar kepemimpinan pelayanan, dengan asumsi dasar bahwa kepemimpinan yang berhasil adalah kepemimpinan yang mengenal, memahami, mendalami dan menghargai nilai- nilai budaya yang tumbuh dan berkembang di dalam masyarakat.

Selanjutnya, konsep kecerdasan sosial sebagai konsep kepemimpinan pelayanan menunjuk pada suatu kemampuan seorang pemimpin terhadap aspirasi masyarakat yang dilayani. Adapun kecerdasan spiritual sebagai dasar dan landasan kepemimpinan pelayanan, bahwa dipercaya sentuhan spiritual akan lebih efektif dibandingkan pendekatan lain.

Sentuhan spiritual bukan permasalahan agama, tetapi lebih pada suatu model pelayanan yang selalu dikaitkan hubungannya dengan kekuasaan Tuhan Yang Maha Melayani. Semua konsep dasar dari kepemimpinan berbasis pelayanan, menunjukkan bahwa diperlukan suatu proses yang cukup panjang untuk mempersiapkannya. Seperti telah dikemukakan, negara Singapura memerlukan waktu 40 tahun lebih untuk rnenghasilkan kepemimpinan berbasis pelayanan. 
Singapura yang tidak memiliki sumber daya alam yang melimpah dapat survive dan memiliki daya saing tinggi, hal ini oleh karena para pemimpin aparatur negaranya memiliki daya saing tinggi di bidang kepemimpinan berbasis pelayanan.

Dengan demikian, model kepemimpinan yang melayani membu- tuhkan suatu perubahan dalam sikap mental lebih daripada sekedar perubahan struktural. Untuk beroperasi di dalam model ini, para pemimpin harus menyisihkan ego mereka dan merangkul secara mendalarn keyakinan bahwa orang- orang akan melakukan kinerja terbaik mereka dalam suatu atmosfer kebebasan dan kepercayaan.

\section{Simpulan}

Suatu negara bangsa tetap rnampu bersaing, para pemimpinnya (aparatur negara) harus menciptakan suatu bangunan sosial yang mampu menghasilkan modal intelektual atau kekuatan pikiran. Kepemimpinan aparatur negara akan menjadi mata uang Abad ke-21. Kita harus menginvestasikannya dengan bijak bagi generasi sekarang dan masa datang. Para pemimpin harus bersedia berbagi semangat dan keahlian yang dimiliki dalam memberdayakan orang lain, supaya menjadi pemimpin yang efektif. Para pemimpin aparatur negara, sebaiknya dapat menjadi inspirasi bagi anak buahnya khususnya dan masyarakat pada umumnya, sehingga mampu memicu clan memacu potensi manusiawi mereka yang besar, menantang gagasan konvensional, mengambil resiko dalam upaya rnengejar sasaran dan impian, menciptakan antusiasme kesempumaan, dan memfokuskan diri pada visi yang memimpin organisasi maupun negara kita serta merangkul umat manusia.

Kunci paradigma baru kepemimpinan aparatur negara adalah, kepemimpinan yang transformasional, transaksional, resonan dan memiliki jiwa pelayanan kepada masyarakat serta keberanian untuk hidup berdasarkan visi yang kuat. Salah satu tema visi yang paling sering dijumpai, yaitu membuat perbedaan. Hal lain yang tidak kalah penting adalah serangkaian harga diri, nilai-nilai yang di dasarkan pada standar kesempurnaan tertinggi yang mungkin diraih. Sebagian nilai yang paling memiliki sifat pemberdayaan diri adalah integritas, kejujuran, kepercayaan, sikap optimis, tanggung jawab pribadi, menghormati semua orang, dan terbuka terhadap perubahan. Nilai-nilai ini membawa dampak mendalam terhadap kesehatan, kemakmuran, dan kesuksesan hidup kita.

Masalah yang menghadang hampir semua pemimpin di masa mendatang adalah bagaimana mengembangkan arsitektur sosial organisasi mereka, sehingga dia sungguh mampu menciptakan modal intelektual. Pada kebanyakan organisasi termasuk organisasi pemerintah, tidak memiliki cara untuk mengukur apa yang disebut sebagai modal intelektual. Tetapi, apabila kita menanyakan orang- orang di berbagai organisasi mengenai seberapa besar pikiran mereka dimanfaatkan dalam tugas- tugasnya, jawaban standamya kira- kira 20 persen. Karena itu, apabila kita menambahkan 10 persen saja kepadanya, coba bayangkan akan seperti apa organisasi-organisasi kita.

Apa yang harus dipelajari untuk dilakukan oleh para pemimpin adalah mengembangkan arsitektur sosial yang mendorong orang-orang yang amat cerdas, yang kebanyakan memiliki ego yang besar untuk bekerja bersama dengan berhasil, dan memanfaatkan kreativitas mereka sendiri. Karena itu, tantangan besar bagi para pemimpin di Abad ke-21 adalah bagaimana membebaskan kekuatan pikiran dari organisasi mereka. Saya kira, ini merupakan tantangan yang mendasar dan cukup berbeda dari tantangan yang dihadapi oleh para pemimpin Abad ke-21.

Lebih dari itu, mengingat untuk membangun kepemimpinan yang berbasis pelayanan selain menuntut cukup banyak persyaratan, juga melalui suatu proses panjang. Paradigma lama yang ingin cepat- cepat mendudukan seseorang menjadi pimpinan, tetapi tidak mempertimbangkan kualifikasi dan kompetensinya, hanya akan meng- hasilkan para pemimpin yang tidak memiliki kepemimpinan yang dibutuhkan organisasi. Masa sekarang cukup banyak pemimpin yang dibutuhkan organisasi. Masa sekarang cukup banyak 
pemimpin tetapi sulit mencari sosok pemimpin yang memiliki kepemimpinan dengan persyaratan sebagau telah dikemukakan (transformasi, transaksional, resonan/ primal, dan berhati pelayanan). Dengan kata lain, kita sedang menghadapi krisis kepemimpinan aparatur negara yang sudah pada tingkat membahayakan.

Belajar dari pengalaman negara dan bangsa lain yang telah berhasil dan maju berkembang, maka sudah saatnya kita menyiapkan kader bangsa untuk pemimpin masa depan. Masalah pemimpin tidak hanya sekedar melalui pilkada dan sejenisnya, yang perlu dilakukan adalah apakah para pemimpin yang mengikuti kontes tersebut sudah dipersiapkan dengan baik. Sudah cukup lama masyarakat mengalami penderitaan sebagai akibat para pemimpin yang tidak memiliki hati memberikan pelayanan dan kasih kepada masyarakat.

Mengingat membentuk sosok kepemimpinan yang kita harapkan, memerlukan suatu proses maka penyiapannya harus benar-benar baik dan direncanakan dengan mantap. Salah satu instrumen yang handal adalah melalui jalur pendidikan, yang didukung oleh tingkat kesejahteraan, ekonomi, kesehatan, kenyamanan serta keamanan yang mantap. Dengan kata lain, mernbangun ke pemimpinan nasional menuntut komitmen pribadi, organisasional dan sosial yang tinggi dari semua pihak.

Kita harus yakin bahwa bangsa Indonesia yang telah teruji melalui masa perjuangan melawan penjajah dan krisis yang lain, harus mampu juga membangun paradigma baru kepemimpinan aparatur negara demi bangsa dan negara yang aman, makmur dan berkeadilan. Dengan demikian paradigma baru kepemimpinan aparatur negara adalah, kombinasi dari konsep kepemimpinan transformasional, transaksional, resonan, memiliki jiwa pelayanan kepada masyarakat serta keberanian untuk hidup berdasarkan visi yang kuat yang dilengkapi keunggulan prima (superleadership) dan mampu mengelola beragam budaya (multicultural leadership), yang diharapkan mampu hidup dan berkembang serta eksis dalarn lingkungan yang hiperkompetisi.

Untuk dapat berada dalam barisan kader pimpinan bangsa yang handal dan terpercaya, terdapat sejumlah persyaratan lain kompetensi kepemimpinan aparatur negara disamping berbagai kemampuan profesional berupa knowledge, technical know-how, dan managerial know-how, yaitu konsis- tensi perilaku berupa komitmen dan kemampuan menerjemahkan falsafah hidup negara bangsa menjadi sikap hidup dan cara hidup individual, serta kebijakan -kebijakan institusional dalam sistem, proses, dan kebijakan kebijakan pemerintahan dan pembangunan, dalam perjuangan mewujudkan cita-cita dan tujuan berbangsa dan bernegara.

\section{Daftar Pustaka}

Albrow, M. 1990. Introduction. Dalam M. Albrow dan E. King (Eds.) Globallization, Knowledge, and Society. London: SAGE.

Archer, Margareth S. 1999. Sociology for One World: Unity and Diversity. International Sociology, (6)2.

Barber, Bernard. 1952. Science and Social Order. New York: Free Press.

Bass, B. M. 1993. Leadership and Performance Beyond Expectation. New York: Free Press.

Bennis, Warren \& Michael Mische. 1995. The $21^{\text {st }}$ Century Organization: Reinventing Through Reengeneering. San Diego: Published by Pfieffer \& Company.

Bennis, Warren \& Robert Townsend. 1998. Reinventing Leadership ((Terjemahan oleh Clara Suwendo. Menciptakan Kembali Kepemimpinan). Batam Centre: Interaksara.

Bethel, Sheila Murray. 1994. Making A Diference (Terjemahan oleh Meitasari Tjandrasa). Jakarta: Binarupa Aksara.

Blanchard, Ken. 2001. The Heart of $A$ Leader (Terjemahan oleh Arvin Saputra. Hati Seorang Pemimpin). Batam Centre: Interaksara. 
Blanchard, Ken, Patricia Zigarmi, dan Drea Zigarmi. 2001. Leadership and The One Minute Manager dalam Ken Blanchard, Hati Seorang Pemimpin (Terjemahan oleh Arvin Saputra). Batam Centre: Interaksara.

Chaffee, Paul. 1997. Accountable Leadership: A Resource Guide for Sustaining Legal, Financial, and Ethical Integrity in Today's Congregations (Revised and Updated). San Francisco: Jossey - Bass Inc., Publisher.

Cherrington, David J. 1995. The Management of Human Resource. 4th Edition. New Jersey: Prentice-Hall Englewood.

Correctional Quality Managerial Leadership. 2001. http://www. de.state.fl. us/ pub/ annual/ 9697 I cqml.html:

Cooper, Robert K. and Ayman Sawaf. 1998. Executive EQ; Emotional Intelligence in Leadership and Organization (Terjemahan oleh Alex Tri Kantjono Widodo). Jakarta: PT Gramedia.

Cooper, Cary L. and Peter Makin. 1995. Psychology for Managers. Cetakan Pertama. (Terjemahan oleh Lilian Yuwono). Jakarta: Penerbit Arean.

Drucker, Peter F. 1999. The Management Chalenges for $21^{\text {st }}$ Century. New York: McGraw-Hill Inc.

Dwiyanto, Agus (ed.). 2006. Mewujudkan Good Governance Melalui Pelayanan Publik. JICAGajah Mada University Press.

Feldman, Robert S. 1992. Element of Psychology. New York: McGraw- Hill, Inc

Gardiner, Gareth S. 1996. $21^{s}$ Century Manager : Meeting The Challenges And Opportunities of The New Corporate Age. New Jersey: Peterson/Pacesetter Books.

Gaefield, Charles A. 1991. Quality: The Art and Science of Business Management Leadership. Dale Timpe (ed.). New York : KEND Publishing, Inc.

Gibson, Ivancevich, and Donnely. 1993. Organization and Management: Behavior, Structure, Process. 4th Edition. (Terjemahan oleh Djoerban Wahid, Cetakan Kedelapan). Jakarta: PT Gelora Aksara Pratama.

Gibson, Rowan. 1998. Rethinking The Future: Rethinking Business, Principles, Competition, Control, Leadership, Markets, and the World (Terjemahan oleh Wandi S. Brata dan Hikmat Kusumaningrat). Jakarta: PT Gramedia.

Goleman, Daniel, Richard Boyatzis, Annie McKee. 2006. Primal Leadership; Realizing the Power of Emotional Intelligence. New Jersey: John Wiley \& Sons. Inc.

Gunterz, Judith P. 1997. Reinventing Human Resource Development. Guam: College of Business and Public Administration.

Hamel, Gary \& C. K. Prahalad. 1994. Competing for the Future (Terjemahan oleh Agus Maulana). Cetakan Pertama. Jakarta Binarupa Aksara.

Harper, Stephen C. 2001.The Forward Focused Organizations: Visionary Thinking and Breakthrough Leadership to Create your company's Future York: AMACOM.

Henry, Nicholas. 1992. Public Administration and Public Affairs, Englewood Cliffs. New Jersey: Prentice Hall.

Hesselbein, Frances. 2007. Change; Ho To Be A Leader for The Future (Terjemahan oleh Emmy Nur Hamid). Jakarta: Pustaka Pelajar.

Hocking dan Boggardus. 1994. "Leadership" (dalam John R. Schermerhorn, Jr., James G. Hunt, and Richard N. Osborn). Organizational Behavior). New York: John Willey \& Sons, Inc. 1994.

Holland, Ian, Jenny Fleming. 2003. Government Reforming: Values and New Political Institutions. England: Ashagate Publishing Limited.

James McGregor Bums. 1978. Leadership. New York: Harper \& Row. 
Joiner, Brian. 1994. The Fourth Generation of Management. New York: McGraw-Hill.

Juran, J. M. 1989. Juran on Leadership for Quality. MacMillan: Free Press, Inc.

Kouzes, James M. and Barry Z. Posner. 1995. The Leadership Challenge: How to Keep Getting Extraordinary things done in Organization. San Francisco: Josssey-Bass Inc.

Kotter, John P. 1998. "What Leaders Really Do". Harvard Business Review on Leadership. Harvard Business School Press, 1998.

Levine, Charles H., B. Guy Peters \& Frank J. Thompson. 1990. Public Administration: Challenges, choice Consequences. USA: Scott, Foresman and Company.

Manz, Charles C. \& Henry P. Sims, Jr. 1990. Super-Leadership: Leading Others To Lead Themselves. New York: Berkley Books.

Mayo, Elton. 1933. The Human Problems of Industrial Civilization. New York.

Mintzberg, Henry. 1998. "The Manager's Job: Folklore and Fact". Harvard Business Review on Leadership. Harvard Business School Press.

Moestopadidjaja. 1997. "Transfonnasi Manajemen Menghadapi Globalisasi Ekonomi." Jurnal Administrasi dan Pembangunan, Vol. 1 No. 1. PP. PERSADI.

Moran, Robert T. John R. Riesenberger. 1993. The Global Challnge: Building the New Worldwide Enterprise. London: Mc Graw Hill Book Company.

Morgan, Howard, Phil Harkins \& Marshall Goldsmith. 2005. The Art \& Practice of Leadership Coaching. New Jersey: John Wiley \& Sons. Inc.

Mouzelis, Nicos P. 1975. Organization and Bureaucracy. Chicago: Aldine Publishing Company.

Murphy, Emmet C. 1996. Leadership IQ. John Wiley \& Sons, Inc.

Ohmae, Kenichi. 1999. The Borderless World: Power and Strategy in the Interlinked Economy (Management Lessons in the New Logic of The Global Marketplace). Revised Edition. New York: McKensey \& Company, Inc.

Ohmae, Kenichi. 1999. T11e Borderless World: Power and Strategy in the Interlinked Economy (Management Lessons in the New Logic of the Global Marketplace). New York: McKensy \& Company

Osborne, David dan Ted Gaebler. 1994. Reinventing Government: How the Entrepreneurial Spirit is Transforming the Public Sector. New York: Penguin Books.

Osborne, David dan Peter Plastrik. 1993. . Banishing the Bureaucracy. New York: Addison Wesley.

O'Toole, James. 2003. Leadership A to Z; A Guide for the Appropriately Ambitious. JosseyBass.Inc.

Parsons, Talcott. 1958."Suggestion for a Sociological Approach to the Theory of Organizations", Administrative Science Quarterly (I): 63-85.

Pegg, Mike. 1994. Positive Leadership (Terjemahan oleh Arif Suyoko). Cetakan Pertama. Jakarta: Pustaka Binaman Pressindo.

Peters, B. Guy. 2001. T1 le Future of Governing. Second Ed (Revised). Kansas: University Press of Kansas.

Peter, Jan Hendrik. 2000. Service Management: Managing the Image. Jakarta:Trisakti University Press.

Pierce, Jon L. \& John W. Newstrom. 2006. Leaders \& The Leadership Process. New York: McGraw -Hill International Edition.

Propenko, Joseph M. dan Igor Pavin (eds). 1991. Enterpreneurship Development in Public Enterprise. Geneva: ILO. 
Public Inspiration: Jurnal Administrasi Publik, 6 (2) (2021), 181

Tantangan Ilmu Administrasi Publik: Paradigma Baru Kepemimpinan Aparatur Negara

Rhinesmith, Stephen H. 1996. A Management Guide to Globalization:Six Skill for Success in a Changing Word, Chicago: ASTD \& Irwin

Robbins, Stephen P. dan Mary Coulter. 1999. Management. 6th Edition. New Jersey: Englewood Cliffs Prentice-Hall, Inc.

Savage, Charles. 1997. The Fifth Generation of Management. New York: McGraw-Hill, Inc.

Stoner, James A. F. dan Charles Wankel. 1996. Management. New Jersey: Simon \& Shuster Prentice - Hall.

Shafritz, Jay M., E. W. Russel, Christopher P. Borick. 2007. Introducing Public Administration. Pearson Education, Inc.

Shelton, Ken (ed.). 2002. A New Paradigm of Leadership (Terjemahan oleh Oka). Jakarta: PT Elex Media Komputindo.

Smith, Gregory P. 1997. The New Leader: Bringing Creativity and Innovation to the Workplace. Danvers: St. Lucie Press.

Stogdill, R. M. 1974. Handbook of Leadership. New York: The Free Press.

Tjokrowinoto, Mulyarto. 2003. "Prospek dan Tantangan Ilmu Administrasi di Era Globalisasi." (Makalah).

Vroom, H. Victor \& G. Arthur Jago. 1988. The New Leadership: Managing Participation in Organization. New York: Prentice- Hall, Englewood.

White, Randall P., Philip Hodgson \& Stuart Crainer. 1997. The Future of The Leadership (Terjemahan oleh Hari Suminto). Batam Center: Interaksa.

Yuki, Gary A. 2002. Leadership in Organization. 3rd Edition. New York: Prentice-Hall, Englewood. 